\title{
Hyaluronan and Hyaladherins in Limb Development
}

\author{
四肢発生におけるヒアルロナンとヒアルアドヘリン \\ Bryan P. Toole \\ Department of Anatomy and Cellular Biology, Tufts University Health Science Schools, \\ Boston, MA 02111, USA, FAX:1-617-956-6536
}

\begin{abstract}
Key Words: hyaluronan, cell-matrix interactions, hyaladherin, extracellular matrix in development, limb development
\end{abstract}
\begin{abstract}
Extracellular matrices in which cells migrate and proliferate during embryonic development are enriched in hyaluronan. Hyaluronan-binding proteins, termed hyaladherins, are a group of related proteins that serve as structural components of these extracellular matrices and as receptors at the surface of the cells therein. Recent evidence indicates that these proteins are involved in assembly of hyaluronan-rich, pericellular matrices and in aspects of cell behavior, especially cell migration and aggregation. Mesodermal cells of the early developing limb are surrounded by a hyaluronan-rich matrix, the production of which is regulated by basic fibroblast growth factor(FGF). When the cells of the chondrogenic and myogenic regions of the mesoderm condense, the cells produce less hyaluronan and become separated by a smaller volume of matrix. FGF levels diminish in the limb at this time but an FGF-like factor produced by the ectoderm maintains the high level of hyaluronan present in the periphery of the limb. Also at the condensation stage, the mesodermal cells exhibit increased levels of hyaluronan-binding sites on their surface. Endogenous cell surface hyaluronan bound to these sites can crossbridge adjacent cells, adhering them to one another, due to multivalent binding. Thus condensation can be explained, at least in part, by three facets of hyaluronan-cell interactions: 1) receptor-mediated endocytosis of pre-existing pericellular hyaluronan; 2) decreased hyaluronan production leading to cessation of coat production; 3 ) stabilization of the condensate by hyaluronan-receptor crossbridging. During differentiation of the condensed mesoderm to cartilage, hyaluronan-binding sites persist on the cell surface. These sites are also essential for assembly of the pericellular matrix surrounding chondrocytes.
\end{abstract}

\section{要 旨}

胚発生の過程において細胞が移動し増殖する場である細胞 外マトリクス中には、ヒアルロナン(ヒアルロン酸)が多量に存 在することが知られている。ヒアルアドヘリンと命名されたヒ アルロナン結合蛋白質は、これら細胞外マトリクスの構成成分 として機能しているものや、細胞外マトリクス中に存在する細 胞表面において受容体として機能しているものからなる蛋白質 の一グルーブを構成している。最近の研究によると、これら一 群の蛋白質は、ヒアルロナンを多量に含む細胞周辺マトリクス の構築に関与し、細胞の行動に関しては、特に細胞の移動と凝 集に関係していることが明かにされている。発生初期の肢芽の 中肧葉細胞はヒアルロナンを多量に含むマトリクスで覆われて おり、その合成は塩基性織維芽細胞成長因子(FGF)によって制 御されている。肢芽中胚葉の軟骨及び筋肉形成の領域で、組織 分化に先立って細胞が凝集する際、細胞のヒアルロナン合成は 低下し、その結果、細胞間の空間はより狭くなる。肢芽内の FGFレベルも、この時、減少するが外胚葉で生産されるFGF样 の因子により、肢芽周辺部分に存在するヒアルロナン量は高濃 度に維持される。また細胞凝集が起こる時期には、中肧葉細胞 の表面に存在するとアルロナン結合部位も増加する。この結合 部位に結合している内在性ヒアルロナンは、その多価結合性の ために、隣接する細胞どうしを架橋し、お互いを接着させるこ とができる。このように細胞凝集は、少なくとも部分的には、 ヒアルロナンと細胞間の相互作用で見られる次の三つの過程で 説明することができる。第一は、細胞周辺にすでに存在してい るヒアルロナンの受容体を介したエンドサイトーシス、第二 は、ヒアルロナン合成の低下による細胞周辺層(マトリクス)形 成の停止、第三は、ヒアルロナンと受容体の間の架橋による龊 集状態の安定化である。凝集した中胚葉が軟骨へ分化する間 も、ヒアルロナン結合部位は細胞表面に存在し続ける。このヒ アルロナン結合部位もまた、軟骨細胞を覆う細胞周辺マトリク スの構築に必要不可欠なものである。

\section{A. Introduction}

Extracellular matrices in which cells migrate and proliferate during embryonic development are enriched in hyaluronan (reviewed in ref. 1). The physical and chemical properties of hyaluronan contribute to the structural integrity of embryonic tissues and to the morphogenetic processes that take place within them. One way in which hyaluronan participates in tissue structure is its ability to form meshworks that exert osmotic

\section{A. はじめに}

肧発生の過程において、細胞が移動し増殖する場である細 胞外マトリクス中には、ヒアルロナン(ヒアルロン酸)が多量に 存在することが知られている(文献1に概説)。ヒアルロナンの物 理的及び化学的特性は、肧組織の構造の維持と肧組織中で進行 する形態形成過程に寄与している。ヒアルロナンが組織構造に おいて果たす一つの役割は、浸透圧を生じさせるような網目状 
pressure $(2,3)$. The resultant swelling pressure within the tissue can lead to separation of cellular or fibrous structures or deformation of the tissue, possibly facilitating cell and tissue movements $(1,4)$. In addition, some embryonic cells exhibit large, hyaluronan-dependent, pericellular matrices or "coats"(5) that may influence cell-cell adhesion( 6,7$)$, cell-substratum adhesion(8), proliferation $(9)$, migration $(10,11)$ or differentiation (12).

Interaction of hyaluronan with the cell surface is mediated by membrane-bound receptors (reviewed in ref. 13). Recent work has demonstrated that the hyaluronan receptor of baby hamster kidney and transformed 3T3 cells is a glycoprotein of molecular weight, $\sim 85 \mathrm{kDa}(14)$ that is closely related to the CD44 lymphocyte homing receptor(15-18). We have prepared a monoclonal antibody, MAb IVd4, that recognizes hyaluronan-binding protein with the properties of a hyaluronan receptor in a wide variety of embryonic and transformed cell types (19). The original antigen used for production of MAb IVd4 was a mixture of hyaluronan-binding proteins prepared from chick embryo brain; three proteins in these preparations, of molecular weight 93,91 and $69 \mathrm{kDa}$, are recognized by MAb IVd4. Similar proteins and related variants are recognized by MAb IVd4 in other tissues and cells, and these proteins are probably related to the $85 \mathrm{kDa}$ hyaluronan receptor, and thus to the many variants of $\mathrm{CD} 44(20,21)$, since MAb IVd4 blocks binding of hyaluronan to the $85 \mathrm{kDa}$ receptor on transformed 3 T3 cells $(19)$.

The hyaluronan-binding proteins discussed above, which we have termed the hyaladherins, are related to one another and to other hyaluronan-binding macromolecules involved in extracellular matrix structure (reviewed in ref. 13). The members of this family of proteins serve as structural components of extracellular matrices and as hyaluronan receptors on the cell surface. MAb IVd4 blocks assembly of pericellular matrices produced by a wide variety of cells, e.g. embryonic limb mesoderm, chondrocytes and fibrosarcoma cells $(\mathrm{Yu}$, Banerjee and Toole, unpublished results). The antibody also blocks cell migration, e.g. of endothelial cells and neural crest cells(Banerjee and Toole, unpublished results). The effects of the antibody on pericellular matrix assembly and on cell migration are mimicked by hyaluronan hexasaccharide, a competitive inhibitor of the interaction between polymeric hyaluronan and its receptor. We are currently investigating whether the effects on matrix assembly and migration are directly related, but clearly hyaluronan and hyaladherins are important to both processes.

\section{B. Hyaluronan-Dependent Pericellular Matrices of Limb Mesoderm}

Mesodermal cells in the early chick embryo limb bud are separated by extensive hyaluronan-rich spaces(22) and these cells in culture produce large, hyaluronan-dependent, pericellular matrices or "coats"(5). When the chondrogenic and
構造を形成することである $(2,3)$ 。その䊅果として組織に膨圧が 生じ、細胞間や緎維性構造の分離を引き起こしたり、あるいは 組織を変形させ、おそらく細胞と組織の運動性を高める $(1,4) 。$ さらに、肧細胞のある種のものは、巨大なヒアルロナン依存性 の細胞周辺マトリクスあるいは細胞周辺"層"(5)を持っており、 細胞間の接着(6、7)や細胞と基質間の接着(8)、增殖(9)、移動(10、 11)、あるいは分化(12)に影響を与えている可能性も考えられて いる。

ヒアルロナンと細胞表面の相互作用は、細胞膜に存在する 受容体を介して行われる(文献13に概説)。最近の研究による と、BHK細胞や3T3細胞が発現するヒアルロナン受容体は、リ ンバ球ホーミング受容体であるCD44と非常に類似した、分子量 が約 $85 \mathrm{kDa}(14)$ の糖蛋白質であることが示されている(15-18)。 われわれは、肧の様々な細胞と各種の形質転換した細胞に広く 分布し、ヒアルロナン受容体として機能するヒアルロナン䊅合 蛋白質を認識する単クローン抗体 MAb IVd4 を作製した(19)。 MAb IVd4 の作製に使用されたもともとの抗原は、ニワトリ胚 の脳より調製したヒアルロナン結合蛋白質の混合物であった。 すなわち、MAb IVd4はこの混合物中に存在する、分子量がそ れぞれ93、91、69kDaの三つの蛋白質を認識する。他の組織や 細胞にも、MAb IVd4によって認識される同様の蛋白質や類似 する多型蛋白質が存在することや、また、MAb IVd4 は形質転 換した3T3細胞に存在する $85 \mathrm{kDa}$ のヒアルロナン受容体とヒア ルロナンとの結合を阻害することから(19)、变そらく、これら の蛋白質は85 kDaのヒアルロナン受容体と多くのCD44の多型 (20、21)に類似するものなのであろう。

以上に述べた、我タがヒアルアドヘリンと命名したヒア ルロナン結合蛋白質は、お互いに類似性があり、また細胞外マ トリクス構造に関与する他のヒアルロナン結合巨大分子とも関 連性が知られている(文献13に概説)。この蛋白質ファミリーを 構成する分子群は細胞外マトリクスの構造成分や、細胞表面に 存在するヒアルロナン受容体として機能している。MAb IVd4 は各種の細胞、例えば、肢芽中胚葉細胞、軟骨細胞、轼維肉腫 細胞によって生産される細胞周辺マトリクスの構築を阻害する (Yu、Banerjee及びToole、未公表結果)。また、この抗体は細胞 の移動、例えば、内皮細胞や神経冠細胞の移動も抑制する(Banerjee及びToole、未公表結果)。細胞周辺マトリクスの構築や細 胞の移動に対するこの抗体の阻害作用は、重合性ヒアルロナン と受容体の拮抗阻害物質であるヒアルロナンの六糖体によって も惹き起こすことができる。現在、我々は、マトリクスの構築 と細胞の移動に対する作用が直接関係しているのか解析中であ るが、明かにヒアルロナンとヒアルアドヘリンは両過程におい て重要な機能を担っている。

\section{B. ヒアルロナン依存性の肢芽中胚葉の細胞周辺マトリク ス}

発生初期のニワトリ胚肢芽を構成する中肧葉細胞は、ヒア ルロナンに富む広い空間によって隔てられており(22)、培養す ると巨大なとアルロナン依存性の細胞周辺マトリクスあるいは 細胞周辺"層"を形成する(5)。したがって、生体内で肢芽の軟骨 形成領域及び筋肉形成領域が䧳集する時には、細胞を隔てるマ 
myogenic areas of the limb bud become condensed in vivo, i.e. these cells are separated by a smaller volume of matrix, the isolated mesodermal cells do not exhibit visible coats in culture. This change in the ability to express coats is accompanied by a large decrease in the ratio of hyaluronan to chondroitin sulfate-proteoglycan produced by the condensation-stage mesoderm, as compared to the pre-condensation mesoderm(5).

During differentiation of chondrocytes from condensed mesoderm, the cells again become separated by extensive spaces in vivo; in culture, the chondrocytes re-express large pericellular coats. Chondrocyte coat structure is still dependent on hyaluronan even though proteoglycan is a quantitatively more prominent component than in early mesoderm $(5,23)$. In contrast to chondrogenesis, fusion of myoblasts is accompanied by loss of pericellular coats(24), apparently a necessary step towards differentiation since myoblasts cultured on a hyaluronan substratum fail to fuse(12). Thus there is a close correlation between the presence of large intercellular spaces in vivo and the expression of large hyaluronan-dependent coats in vitro.

\section{Changes in Hyaluronan-Cell Interactions during Con- densation of Limb Mesoderm}

An important stage in differentiation of limb mesoderm is the above-mentioned condensation of cells that precedes final cytodifferentiation of muscle and cartilage. In parallel to the loss of ability to express hyaluronan-dependent coats and the changes in glycosaminoglycan synthesis that occur at this stage, an increase in membrane-associated binding sites for hyaluronan occurs(25). Hyaluronan-binding sites are known, in other systems, to be involved in endocytosis en route to degradation of hyaluronan(26-28), and so it is reasonable to suppose that the increase in hyaluronan-binding sites at the time of condensation represents the onset or increase in receptor-mediated endocytosis of hyaluronan. Decreased hyaluronan synthesis and coat production together with increased endocytosis and degradation of hyaluronan would lead to a dramatic reduction in volume of matrix between the mesodermal cells, thus allowing them to "condense".

In addition to the events leading to reduction in matrix volume, condensation may also involve direct cell interactions (e.g. see refs. 29-31). One such interaction is likely to be crossbridging of cells via multivalent binding of hyaluronan to the cell surface binding sites that are expressed at this stage(25). We have shown previously that $\mathrm{Ca}^{2+}$-independent self-aggregation of transformed cell lines is due to crossbridging by hyaluronan of binding sites on adjacent cells; removal of cell surface hyaluronan or saturation of the binding sites inhibits this crossbridging $(6,32)$. Knudson and Maleski(7) have demonstrated that mesodermal cells from condensation stage limbs, but not cells from pre-condensation limbs, aggregate in vitro via such hyaluronan-mediated crossbridging.

Thus we propose that condensation may be explained in
トリクスの容積は減少し、単離された中胚葉細胞を培養した場 合には顥著な細胞周辺層の形成は見られない。この細胞周辺層 の形成能力の变化には、凝集前の中肧葉細胞と比較すると、凝 集期段階の中胚葉細胞が合成するヒアルロナンのコンドロイチ ン硫酸プロテオグリカンに対する比率の大幅な減少を伴ってい る(5)。

凝集している中肧葉細胞が軟骨細胞へ分化する間に、生体 内の細胞は再び広い空間によって叠てられる。培養でも、再び軟 骨細胞は巨大な細胞周辺層を形成する。軟骨細胞の周辺層の構 造は、発生初期の中胚葉と比較すると、定量的にはプロテオグ リカンが優勢になってくるが、依然としてヒアルロナンが主要 である $(5,23)$ 。軟骨細胞とは対照的に筋芽細胞の融合は細胞周 辺層の消失を伴っており、また、この現象は筋肉分化には必須 の過程である。何故ならば、筋芽細胞をヒアルロナンを基質と して培養すると、細胞は融合できなくなるからである(12)。こ のように生体内において、広い細胞間の空間が存在すること と、培養した場合、巨大なとアルロナン依存性の細胞周辺層を 形成することとの間には密接な関係が存在する。

\section{C. 肢芽中胚葉の凝集過程におけるヒアルロナンと細胞の 間の相互作用の变化}

肢芽中胚葉細胞の分化のおける重要な過程は、すでに述べ たように、筋肉と軟骨への最終的な分化に先立って起こる細胞 凝集である。この段階で見られるヒアルロナン依存性の細胞周 辺層の形成能の整失とグリコサミノグリカンの合成の変化に並 行して、細胞膜に存在するヒアルロナン結合部位が增加する (25)。他の系では、ヒアルロナン結合部位はヒアルロナンを分 解するためのエンドサイトーシスに関与していることが知られ ており(26-28)、したがって細胞凝集時にヒアルロナン䊅合部位 が増加することは、受容体を介したヒアルロナンのエンドサイ トーシスの開始あるいは增加と仮定して良いと思われる。ヒア ルロナン合成と細胞周辺層形成の低下は、ヒアルロナンのエン ドサイトーシス及び分解の増加とあいまって、中肧葉細胞間に 存在するマトリクス容積を的的に減少させ、その結果としで細 胞凝集"を可能にするのであろう。

マトリクス容積の減少に至る諸過程に加え、細胞凝集はま た直接的な細胞間相互作用を惹き起こす可能性もある(例えば文 献29-31参照)。そのような相互作用のひとつは、凝集期に細胞 表面に発現される結合部位とヒアルロナンとの多価䊅合により 䓯き起こされる細胞どうしの架橋であろう(25)。われわれはか つて、形質転換した細胞株のCa ${ }^{2+}$ 非依存性の自己凝集は、瞵接 した細胞上に存在する䊅合部位がヒアルロナンによって架橋さ れることにより惹き起こされることを見いだした。すなわち、 細胞表面のヒアルロナンの除去あるいは䊅合部位の飽和は、こ の細胞どうしの架橋を阻害する(6、32)。KnudsonとMaleski(7)は 凝集期の肢芽中胚葉細胞は、培盖した場合、このようなヒアル ロナンを介する架橋によって疑集し、凝集前の肢芽中胚葉細胞 では、そうではないことを示した。

従って、我々は、細胞凝集は、以下に述べる過程によって その殆どが説明されると考える。

1) 細胞凝集の開始を可能にする、既存のヒアルロナンの受容体 


\section{DIFFERENTATION OF CHONDROCYTES FROM LIMB MESODERM}

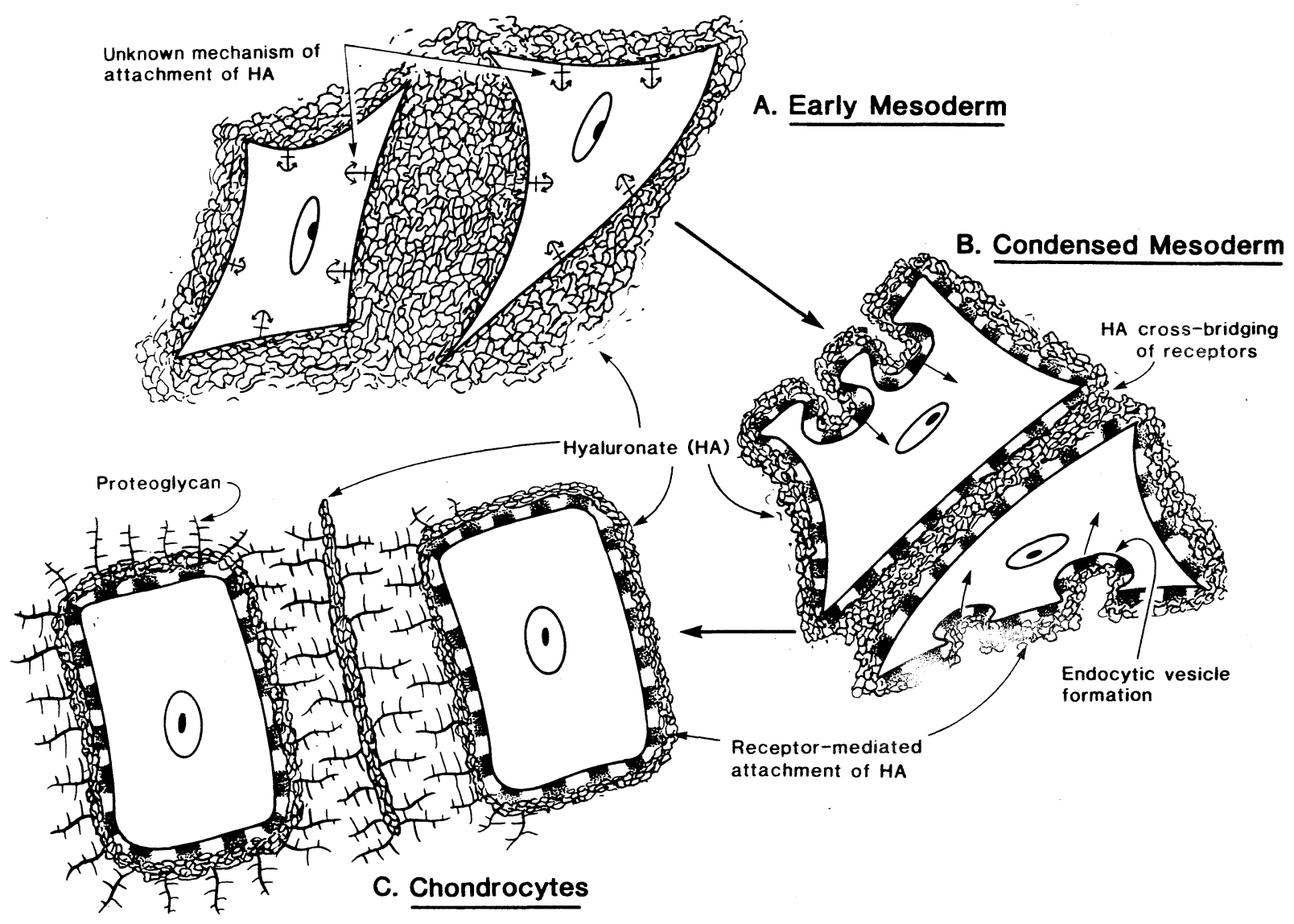

Fig. 1. The hypothesized role of hyaluronan-cell interaction in mesodermal condensation and chondrocyte differentialtion. From ref. 51.

large part by the following events (see Fig. 1):

1) Receptor-mediated endocytosis of pre-existing pericellular hyaluronan, to permit condensation to begin;

2) Decreased hyaluronan synthesis and cessation of coat assembly, to permit condensation to continue;

3) Hyaluronan-mediated crossbridging of cells, to stabilize the condensate.

\section{Hyaluronan-Cell Interactions in Cartilage Differentia- tion}

Recent studies in our laboratory(Tumer, Banerjee and Toole, unpublished results) have shown that interference with binding of hyaluronan, presumably at the surface of mesodermal cells, blocks chondrogenesis as assessed in the micromass culture system of Solursh and colleagues(33). In these studies, chondrogenesis was blocked by treatment of mesodermal cells either with the monoclonal antibody, MAb IVd4, to chick embryo hyaluronan-binding protein or with hyaluronan hexasaccharide which also disrupts binding of polymeric hyaluronan to binding protein. However, further experiments are necessary to distinguish whether hyaluronan and hyaluronan-binding pro-
を介したエンドサイトーシス

2)細胞疑集を持続させる、ヒアルロナン合成の低下と細胞周辺 層形成の停止

3) 細胞凝集状態を安定化させる、ヒアルロナンを介した細胞ど うしの架橋

D. 軟骨分化におけるヒアルロナンと細胞の間の相互作用 最近の我々の研究で(Turner、Banerjee及びToole、未公表結 果)、Solurshら(33)によって開発された微小量培養系で見られる 軟骨分化は、おそらく中胚葉の細胞表面に対するヒアルロナン の結合を阻害することによって抑制されることがわかってい る。また、この研究では、中肧葉細胞をニワトリ胚のヒアルロ ナン結合蛋白質に対する単クローン抗体である MAb IVd4 で処 理したり、あるいは、重合性ヒアルロナンが結合蛋白質に対し て結合するのを阻害するヒアルロナンの六糖体で処理すること によっても軟骨分化が抑制された。しかしながら、ヒアルロナ ンとヒアルロナン結合蛋白質が、以下に述べるマトリクス構築 に加え、細胞凝集あるいは細胞分化に直接に関与しているかど うか判断するためには更に研究が必要である。

多くの研究が、成熟した軟骨細胞によるマトリクス構築にヒア 
teins are directly involved in cell aggregation or differentiation in addition to their role in matrix assembly, discussed below.

Many studies indicate that hyaluronan plays an important role in matrix assembly by mature chondrocytes; for example, the well-documented interaction of hyaluronan with link protein and proteoglycan is central to the structure of cartilage matrix(34). Recent evidence indicates that retention of hyaluronan-proteoglycan aggregates in the pericellular matrix by binding to other hyaluronan-binding proteins is also important. As mentioned above, chondrocytes in culture exhibit pericellular coats that have provided a useful in vitro model for studying the pericellular matrix of chondrocytes. Using this system it has been shown, first, that chondrocyte coats are destroyed by treatment with hyaluronan-specific hyaluronidase, and that this loss of coats is accompanied by release of much of the proteoglycan associated with the chondrocyte cell layer, thus indicating that it was retained in the cell layer by interaction with hyaluronan $(23,35)$. Second, production of these pericellular coats by chondrocytes is inhibited by hyaluronan hexasaccharide(36) or the antibody to hyaluronan-binding protein, MAb IVd4(Yu, Banerjee and Toole, unpublished results). MAb IVd4 reacts strongly with embryonic cartilage but only after treatment of the tissue with hyaluronan-specific hyaluronidase, implying that the binding protein is also occupied by hyaluronan in vivo. The relationship of the proteins recognized by MAb IVd4 to other hyaluronan-binding proteins in cartilage $(35,37)$ is not yet known. Third, pericellular coats can be rebuilt around cells that exhibit hyaluronan-binding sites, but not around cells lacking such sites, by addition of hyaluronan and cartilage proteoglycan. This process is inhibited in the presence of hyaluronan hexasaccharide(38). Since hyaluronan hexasaccharide does not inhibit hyaluronan-link protein or hyaluronan-proteoglycan binding(39) but does inhibit hyaluronan interaction with the proteins recognized by MAb IVd4 (19), we conclude that hyaluronan-proteoglycan aggregates are retained in the pericellular matrix or at the chondrocyte surface by interaction with the hyaluronan-binding proteins recognized by MAb IVd4(Fig. 1).

\section{E. Regulation of Hyaluronan Synthesis and Coat Forma- tion}

A positive relationship appears to exist between hyaluronan synthesis and cell proliferation(9), two prominent activities during the earliest stages of limb development. Basic FGF is a major growth factor in the early developing limb. The amount of this factor is highest in pre-condensation stage limb buds, when hyaluronan synthesis and cell proliferation are maximal, and decreases during subsequent condensation and differentiation of the mesoderm $(40,41)$. Basic FGF stimulates hyaluronan synthesis and hyaluronan-dependent coat formation in cultures of limb mesoderm(42). Thus FGF may be important in the coordinated regulation of cell proliferation, hyaluronan synthesis and pericellular matrix assembly in the pre-
ルロナンが重要な役割を果たしていることを示している。例 えば、十分証明されているように、ヒアルロナンとリンク蛋 白質及びプロテオグリカンとの相互作用は、軟骨マトリクス構 造を形成する上で中心的な機能を果たしている(34)。近年の研 究によると、細胞周辺マトリクス内でのヒアルロナン-ブロテオ グリカン会合体を、他のヒアルロナン結合蛋白質を介した結合 によって保持することもまた重要であることが示されている。 すでに述べたように、培養された軟骨細胞は細胞周辺層を形成 するので、軟骨細胞の細胞周辺マトリクスを研究する上で有用 な in vitroでのモデルとなる。この系を用いることにより、次 のことが示されてきた。第一は、ヒアルロナン特異的なヒアル ロニダーゼで处理することにより、軟骨細胞の細胞周辺層は破 壊され、さらに細胞周辺層の消失には軟骨細胞層に存在するフ ロテオグリカンの多量の放出を伴うことが明かにされており、 このことはプロテオグリカンはヒアルロナンとの相互作用に よって軟骨細胞に保持されていることを意味するものである $(23 、 35)$ 。第二は、軟骨細胞によるこれら細胞周辺層の形成が、 ヒアルロナンの六糖体(36)あるいはヒアルロナン結合蛋白質に 対する単クローン抗体 MAb IVd4 で処理することにより阻害さ れることである(Yu、Banerjee及びToole、未公表䊅果)。MAb IVd4 は肧の軟骨と強固に反応するが、それが見られるのは組織 をヒアルロナン特異的なヒアルロニダーゼで処理した場合のみ であることから、生体内でもとアルロナン結合蛋白質はヒアル ロナンによって占有されていると思われる。MAb IVd4 によっ て認識される蛋白質と軟骨に存在する他のヒアルロナン粘合蛋 白質 $(35,37)$ との関係は今のところ不明である。第三は、破壊さ れた細胞周辺層は、ヒアルロナンと軟骨プロテオグリカンを添 加することにより、ヒアルロナン結合部位を有する細胞の周辺 には再構築されるが、䊅合部位を欠いた紐胞の周辺では見られ ないことである。この過程は、ヒアルロナンの六糖体の存在下 で阻害される(38)。ヒアルロナンの六糖体は、ヒアルロナンと リンク蛋白質あるいはとアルロナンとプロテオグリカンとの結 合は阻害せず(39)、ヒアルロナンと MA b IVd4により認識され る蛋白質との相互作用を阻害することから(19)、われわれは、 ヒアルロナン-プロテオグリカン会合体は、MAbIVd4kより認 識されるヒアルロナン結合蛋白質と相互作用することによって 細胞周辺マトリクスあるいは軟骨細胞の表面に保持されている と考えている(図1)。

\section{E. ヒアルロナン合成及び細胞周辺層形成の制御}

四肢発生の初期段階において、顕著な2つの活性である七 アルロン酸合成と細胞增殖の間には、明かに関連性があると思 われる(9)。塩基性FGFは、発生初期の肢芽において主要な細胞 成長因子である。この因子の量は、ヒアルロナン合成と細胞増 殖が最も活発である凝集前の段階の肢芽で最も大となり、続い て起こる中肧葉の凝集及び分化の段階になると減少する(40、 41)。塩基性FGFは、培盖された肢芽中肧葉に対してヒアルロナ ンの合成とヒアルロナン依存性の細胞周辺マトリクスの形成を 促す(42)。このようにFGFは凝集前の肢芽中胚葉において細胞 增殖、ヒアルロナン合成、及び細胞周辺マトリクスの統括され た制御に重要な役割を果たしていると思われる。FGFを含む拡 
condensation limb bud mesoderm. Diffusible growth factors, including FGF, have been implicated in the growth regulatory effects of the apical ectodermal ridge and zone of polarizing activity of the early limb bud $(43,44)$. Therefore it will be of interest to determine whether these regions of the limb also influence hyaluronan-rich matrix assembly, and whether this potential effect contributes to their morphogenetic roles.

Interaction of limb mesoderm and ectoderm is important in the regulation of morphogenesis and differentiation in the limb bud. The subectodermal mesoderm remains non-condensed during premyogenic and prechondrogenic condensation, retaining mesenchymal morphology and large hyaluronan-rich spaces between cells(22). This regionalization of condensed and non-condensed mesoderm appears to be under the control of the ectoderm since factors produced by the ectoderm prevent differentiation of nearby mesoderm to cartilage and cause the retention of mesenchymal characteristics, including hyaluronan-rich intercellular spaces(45-47). We have found that ectodermal cells in culture produce a factor or combination of factors that stimulate hyaluronan synthesis and formation of hyaluronan-dependent coats in condensation-stage mesodermal cells(48). Preliminary evidence suggests that the ectodermal factor(s) includes basic FGF and TGF- $\beta$ (Knudson, Munaim and Toole, unpublished results). Basic FGF and TGF$\beta$ both stimulate coat formation, but only FGF duplicates the effects of the ectodermal factor on glycosaminoglycan synthesis (42). We conclude from these studies that the ectoderm produces a factor(s) that causes subjacent mesoderm to maintain a high rate of hyaluronan synthesis relative to the central condensed mesoderm; this effect can largely be explained by ectodermal production of basic FGF but TGF- $\beta$ also appears to play a role.

Thus a combination of regulatory factors, including factors related to FGF and TGF- $\beta$, may regulate regional matrix production during condensation and other morphogenetic events in the limb bud. Cooperative effects between factors related to FGF and TGF- $\beta$ have been demonstrated in other morphogenetic systems (see refs. 49,50), and these agents interact with and influence the composition of extracellular matrices. It is anticipated, then, that future research will continue to focus on their important role in regulation of early morphogenetic events in the limb.
散性の細胞成長因子は、発生初期の肢芽に存在する外胚葉性頂 堤、及び極性化活性带における增殖調節作用に関与していると

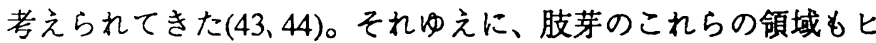
アルロナンを多量に含むマトリクスの構筑に影響を与えるかど うか、そしてこの潜在的な作用が、両領域の形䔮形成における 役割に寄与しているのかどうか解析することは興味深いことで あろう。

肢芽中胚葉と外胚葉は、肢芽の形態形成と細胞分化の調節 に重要な役割を果たしている。外肧葉直下に位圈する中肧葉 は、他の中胚葉が筋肉及び軟骨分化に先行する細胞凝集を行う 間に、非凝集状態に保たれ、間充織の形態とヒアルロナンに富 む広い細胞間の空間を維持し続ける(22)。この凝集、非凝集状 態の中肧葉の部域化は、外胚葉によって制御されていると思わ れる。なぜなら、外胚葉で産生される因子は、近傍に位置する 中肧葉の軟骨分化を抑制し、ヒアルロナンに富んだ細胞間空間 などの間充織の特徵を維持し続けるからである(45-47)。我々 は、培盖された外胚葉が、細胞凝集段階にある中胚葉細胞に対 してヒアルロナン合成とヒアルロナン依存性の細胞周辺層の形 成を促す単一あるいは複合因子を生産することを見いだした (48)。予備実験の結果から、外胚葉の因子(群)には、塩基性FGF 及びTGF- $\beta$ が含まれていることが示唆されている(Knudson、 Munaim及びToole、未公表䊅果)。塩基性FGFとTGF- $\beta$ は共に細 胞周辺層の形成を促進するが、FGFのみが外肧葉性因子のグリ コサミノグリカン合成に对する作用を再現できる(42)。我タ は、これらの研究から外肧葉は、その直下に位置する中肧葉の ヒアルロナン合成能を、中心部に位置する凝集状態の中胚葉に 較へてて高い状態に維持する因子(群)を生産している、つまり、 この作用はTGF- $\beta$ も役割を果たしていると思われるが、外胚葉 が生産する塩基性FGFが主体になって作用していると考えてい る。

このように、FGF、TGF- $\beta$ に類似する因子を含む調節因子 の組み合せによって、肢芽の細胞凝集及び他の形態形成過程に おける部域的なマトリクス合成の制御がなされているのかもし れない。FGF及びTGF- $\beta$ に類似する因子間の協同的な作用は、 他の形態形成系でも示されており (文献49、50参照)、さらに、こ れらの作用物質は、細胞外マトリクスの構成成分と相互作用し 影響を与える。したがって、今後、これらの因子群が果たす四 肢の初期形態形成過程の制御における重要な役割に対して、研 究の焦点が当てられてゆくことが予想される。

\section{三菱化成生命科学研究所 神経発生学 内山 孝司 訳}

\section{References}

1. Toole, B.P. (1981) in Cell Biology of Extracellular Matrix (Hay, E.D., ed.) pp. 259-294, Plenum, New York

2. Comper, W.D., and Laurent, T.C. (1978) Physiol. Rev. 58, 255-315

3. Meyer, F.A. (1983) Biochim. Biophys. Acta 755, 388-399

4. Morris-Wiman, J., and Brinkley, L.L. (1990) Anat. Rec. 226, 383-395

5. Knudson, C.B., and Toole, B.P. (1985) Develop. Biol. 112, 308-318

6. Underhill, C.B., and Toole, B.P. (1981) Exp. Cell Res. 131, 419-423

7. Knudson, C.B. and Maleski, M.P. (1987) J. Cell Biol. 105, 141a

8. Barnhart, B.J., Cox, S.H., and Kraemer, P.M. (1979) Exp. Cell Res. 119, 327-332

9. Brecht, M., Mayer, U., Schlosser, E., and Prehm, P. (1986) Biochem. J. 239, 445-450 
10. Turley, E.A., Bowman, P., and Kytryk, M.A. (1985) J. Cell Sci. 78, 133-145

11. Schor, S.L., Schor, A.M., Grey, A.M., Chen, J., Rushton, G., Grant, M.E., and Ellis, I. (1989) In Vitro Cell Develop. Biol. 25, 737-746

12. Kujawa, M.J., Pechak, D.G., Fiszman, M.Y., and Caplan, A.I. (1986) Develop. Biol. 113, 10-16

13. Toole, B.P. (1990) Current Opinion Cell. Biol. 2, 839-844

14. Underhill, C.B., Green, S.J., Comoglio, P.M., and Tarone, G. (1987) J. Biol. Chem. 262, 13142-13146

15. Aruffo, A., Stamenkovic, I., Melnick, M., Underhill, C.B., and Seed, B. (1990) Cell 61, 1303-1313

16. Culty, M., Miyake, K., Kincade, P.W., Sikorski, E., Butcher, E.C., and Underhill, C. (1990) J. Cell Biol. 111, 2765-2774

17. Lesley, J., Schulte, R., and Hyman, R. (1990) Exp. Cell Res. 187, 224-233

18. Miyake, K., Underhill, C.B., Lesley, J., and Kincade, P.W. (1990) J. Exp. Med. 172, 69-75

19. Banerjee, S.D., and Toole, B.P. (1991) Develop. Biol. 146, 186-197

20. Brown, T.A., Bouchard,T., St. John, T., Wayner, E., and Carter, W.G. (1991) J. Cell Biol. 113, 207-221

21. Stamenkovic, I., Aruffo, A., Amiot, M., and Seed, B. (1991) EMBO J. 10, 343-348

22. Singley, C.T., and Solursh, M. (1981) Develop. Biol. 84, 102-120

23. Goldberg, R.L., and Toole, B.P. (1984) J. Cell Biol. 99, 2114-2122

24. Orkin, R.W., Knudson, W., and Toole, B.P. (1985) Develop. Biol. 107, 527-530

25. Knudson, C.B., and Toole, B.P. (1987) Develop. Biol. 124, 82-90

26. Laurent, T.C., Fraser, J.R.E., Pertoft, H., and Smedsrod, B. (1986) Biochem. J. 234, 653-658

27. McGuire, P.G., Castellot, J.J., and Orkin, R.W. (1987) J. Cell. Physiol. 133, 267-276

28. McGary, C.T., Raja, R.H., and Weigel, P.H. (1989) Biochem. J. 257, 875-884

29. Knudsen, K.A., Myers, L., and McElwee, S.A. (1990) Exp. Cell Res. 188, 175-184

30. Bee, J.A., and von der Mark, K. (1990) J. Cell Sci. 96, 527-536

31. Coelho, C.N., and Kosher, R.A. (1991) Develop. Biol. 144, 47-53

32. Underhill, C.B. (1982) J. Cell Sci. 56, 177-189

33. Solursh, M., Ahrens, P.B., and Reiter, R.S. (1978) In Vitro 14, 51-61

34. Hascall, V.C., and Hascall, G.K. (1981) in Cell Biology of ExtracellularMatrix (Hay, E.D., ed.) pp 39-63, Plenum, New York

35. McCarthy, M.T., and Toole, B.P., (1989) J. Cell. Physiol. 141, 191-202

36. Knudson, C.B., and Kuettner, K.E. (1990) Orthop. Trans 14, 370

37. Crossman, M.V., and Mason, R.M. (1990) Biochem. J. 266, 399-406

38. Knudson, W., and Knudson, C.B. (1991) J. Cell Sci. 99, 227-235

39. Tengblad, A. (1981) Biochem. J. 199, 297-305

40. Munaim, S. I., Klagsbrun, M., and Toole, B.P. (1988) Proc. Natl. Acad. Sci. USA 85, 8091-8093

41. Seed, J., Olwin, B. B., and Hauschka, S.D. (1988) Develop. Biol. 128, 50-57

42. Munaim, S.I., Klagsbrun, M., and Toole, B.P. (1990) Develop. Biol. 143, 297-302

43. Bell, K.M., and McLachlan, J.C. (1985) J. Embryol. Exp. Morphol. 86, 219-226

44. Aono, H., and Ide, H. (1988) Develop. Biol. 128, 136-141

45. Solursh, M., Singley, C.T., and Reiter, R.S. (1981) Develop. Biol. 86, 471-482

46. Hurle, J.M., Ganan, Y., and Macias, D. (1989) Develop. Biol. 132, 368-374

47. Solursh, M. (1990) Seminars Develop. Biol. 1, 45-53

48. Knudson, C.B., and Toole, B.P. (1988) Biochem. Intl. 17, 735-745

49. Smith, J.C. (1989) Development 105, 665-677

50. Whitman, M., and Melton, D.A. (1989) Annu. Rev. Cell Biol. 5, 93-117

51. Toole, B.P., Munaim, S.I., Welles, S., and Knudson, C.B. (1989) Ciba Found. Symp. 143, 138-149

\section{Please Cite Minireviews and Other Articles of TIGG in Your Paper!}

As you see in the cumulative contents of Trends Glycosci. Glycotechnol. Vol. 3(pp.138-141), this journal contains a lot of useful informations. Please cite Trends Glycosci. Glycotechnol., when you write your paper. Citation data of Trends Glycosci. Glycotechnol. are very important!
あなたの論文にTIGGのミニレビューやその 他の論文を引用して下さい!

Trends Glycosci. Glycotechnol. Vol. 3の総目次 (138-141頁)を御覧になれば扮分かりのように、 本誌には有益な沢山の情報が載っています。皆 様が論文を書かれる時にはTrends Glycosci. Glycotechnol.を引用して下さい。Trends Glycosci. Glycotechnol.の引用のデータは重要です! 